\title{
The Effect of Ethanol and Ethyl Acetate Fraction of Chayote fruit (Sechium edule Jacq. Swartz) on the Oxidative Stress and Insulin Resistance of Male White Rat Model Type 2 Diabetes Mellitus
}

\author{
Jekson Martiar Siahaan ${ }^{1,2}$, Syaffruddin Illyas ${ }^{3}$, Dharma Lindarto ${ }^{4}$, Marline Nainggolan ${ }^{5 *}$ \\ ${ }^{1}$ Doctoral Program, Universitas Sumatera Utara, Medan, Indonesia; ${ }^{2}$ Department of Physiology, Faculty of Medicine, Universitas \\ Sumatera Utara, Medan, Indonesia; ${ }^{3}$ Department of Biology, Faculty of Mathematics and Natural Science, Universitas Sumatera \\ Utara, Medan, Indonesia; ${ }^{4}$ Department of Internal Medicine, Faculty of Medicine, Universitas Sumatera Utara, Medan, \\ Indonesia; ${ }^{5}$ Department of Pharmaceutical Biology, Faculty of Pharmacy, Universitas Sumatera Utara, Medan, Indonesia
}

\begin{abstract}
\end{abstract}
Edited by: Igor Spirosk Citation: Siahaan JM, Illyas S, Lindarto D, Nainggolan M. The Effect of Ethanol and Ethyl Acetate Fraction of Chayote fruit (Sechium edule Jacq. Swartz) on the Oxidative Stress and Insulin Resistance of Male White Rat
Model Type 2 Diabetes Mellitus. Open Access Maced J Med Sci. 2020 Dec 15; 8(A):962-969 https://doi.org/10.3889/oamjms.2020.4517 Keywords: Type 2 Diabetes Mellitus, Insulin Resistance,
Streptozotocin, Nicotinamide, High-fat die Pharmaceutical Biology, Faculty of Pharmacy, Universitas Sumatera Utara, Medan, Indonesia. E-mail: linegolan57@gmail.com Received: 27-02-2020 Revised: 20-04-2020 Accepted: $12-12-2020$ Copyright: ๑ 2020 Jekson Martiar Siahaan Syaffruddin Illyas, Dharma Lindarto, Marline Nainggolan Funding: This research did not receive any financial Competing Interest: The authors have declared that no competing interest exists Open Access: This is an open-access article distributed under the terms of the Creative Commons Attribution-
NonCommercial 4.0 International License (CC BY-NC 4.0)

\section{Introduction}

Chronic hyperglycemia induces the increase of oxidative stress due to the uncontrolled reactive oxygen species (ROS) and reactive nitrogen species. This condition plays an important role in tissue destruction of the patients of Type 1 diabetes mellitus (T1D) and Type 2 diabetes mellitus (T2D). There will be damage in pancreatic $\beta$-cell for T1D and insulin resistance or disordered insulin secretion for T2D patients [1], [2], [3]. To measure the ineffective performance of insulin as a result of insulin resistance, as well as to check the function of pancreatic B-cell, homeostatic model assessment of insulin resistance (HOMA-IR) can be used as a measurement [4], [5].
Two main pathophysiology mechanisms of HOMA-IR are dysfunctional pancreatic $B$-cell and insulin resistance [4], [6], [7], [8]. These two mechanisms are underlined by the existence of oxidative stress, the increase of ROS product by hexosamine pathway, advanced glycation end-products, fat acid free, and leptin which produces ROS. The increasing of free radicals will stimulate the formation of adipokines, cytokines, and prostanoids which then cause insulin resistance [3].

The damage of pancreatic $\beta$-cell can be modeled in a hyperglycemic animal model, using streptozotocin (STZ) and nicotinamide (NA) to induce hyperglycemia. STZ may damage the pancreatic $\beta$-cell, however, the NA application may protect pancreatic $\beta$-cell from further damage caused by the STZ effect. 
NA injection after giving STZ with time interval may give partial protection to the ß-cell cytotoxic effect. Effective protection is attained if NA is injected $2 \mathrm{~h}$ after giving the STZ, and less effective protection if the interval is longer. STZ was carried to pancreatic $\beta$-cell through glucose transporter (GLUT2), which may cause DNA damage through the raising of poly(ADP-ribose) polymerase (PARP-1) activities [9], [10].

The abnormality caused by hyperglycemia can be controlled through the oral treatment of antihyperglycemic, which can alternatively be utilized from herbal medicine with anti-hypoglycemia potential and antioxidant activities. According to Siahaan et al. [11], the flavonoid content in the plant, as in chayote (Sechium edule Jacq. Swartz), can decrease the blood sugar level (BSL) and increase the antioxidant level in diabetic mice. There was also a difference in the diameter of the pancreatic $\beta$-cell between chayotetreated mice and non-treated mice [11], [12].

\section{Materials and Methods}

\section{Study site}

This study was undertaken at the Biomedical Laboratory, Faculty of Medicine, University of North Sumatra for a year.

\section{Collection and preparation of plant materials}

Chayote was collected with purposive sampling method from the yards of a citizen of Sidamanik district, Sumatera Utara, Indonesia.

\section{Experimental design}

This research is a laboratory experimental research conducted with a post-test randomized controlled group design using hyperglycemic white male Wistar rat. The design of this research has allowed the measurement of the effect of treatment to the experimental group by comparing the treated group with the untreated/control group. Nonetheless, the design does not allow the measurement of the level of the change caused by the treatment, as there was no initial measurement at the beginning of the research. The treatments to all samples were conducted at the same time and the post-test only control group design was conducted after a certain time. In this design, the sample was obtained using simple random sampling method. Therefore, the animal model, location of experiment, and the materials were homogenous.

\section{Experimental groups}

The animal models used in this research are healthy white male Wistar rats aged 2.5-3 months old, with a body weight between 150 and $220 \mathrm{~g}$. The rats body weight was measured in week 0 to determine if the rats used to fit into the inclusion criteria specified. The selection of rat as a model was based on its genetic similarity with human and their ability to adapt to the laboratory environment. The number of the sample used was determined using randomization method for animal experiment by Federer equation: $(n-1)(t-1) \geq 15$, where $t$ is the number of treatments while $\mathrm{n}$ is the number of animals per treatment. Eleven groups with four male rats each were then used in this research, with 44 male rats as a sample in total.

The following 11 groups of rats were used for the experiments, Group A: Normal untreated rats under ad libitum feeding and drinking condition (the negative control), Group B: Rats were administered with STZ $45 \mathrm{mg} / \mathrm{kg}$ b.w. + NA $110 \mathrm{mg} / \mathrm{kg}$ b.w. + high-fat diet (HFD) (the positive control), Group C: Rats were administered with STZ $45 \mathrm{mg} / \mathrm{kg}$ b.w. + HFD (the positive control), Group D: Rats were administered with NA $110 \mathrm{mg} / \mathrm{kg}$ b.w. + HFD (the positive control), Group E: Rats were administered with STZ $45 \mathrm{mg} / \mathrm{kg}$ b.w. + NA $110 \mathrm{mg} / \mathrm{kg}$ b.w. + HFD + chayote ethanol extract $45 \mathrm{mg} / \mathrm{kg}$ b.w., Group F: Rats were administered with STZ $45 \mathrm{mg} / \mathrm{kg}$ b.w. + NA $110 \mathrm{mg} / \mathrm{kg}$ b.w. + HFD + chayote ethanol extract $100 \mathrm{mg} / \mathrm{kg}$ b.w., Group G: Rats were administered with STZ $45 \mathrm{mg} / \mathrm{Kg}$ b.w. + NA $110 \mathrm{mg} / \mathrm{kg}$ b.w. + HFD + chayote ethanol extract $150 \mathrm{mg} / \mathrm{kg} \mathrm{b.w.,} \mathrm{Group} \mathrm{H:}$ Rats were administered with STZ $45 \mathrm{mg} / \mathrm{kg}$ b.w. + NA $110 \mathrm{mg} / \mathrm{kg} \mathrm{b.w.} \mathrm{+} \mathrm{HFD} \mathrm{+} \mathrm{ethyl} \mathrm{acetate} \mathrm{fraction} \mathrm{of}$ chayote extract $45 \mathrm{mg} / \mathrm{kg}$ b.w., Group I: Rats were administered with STZ $45 \mathrm{mg} / \mathrm{kg}$ b.w. + NA $110 \mathrm{mg} / \mathrm{kg}$ b.w. + HFD + ethyl acetate fraction of chayote extract $100 \mathrm{mg} / \mathrm{kg}$ b.w., Group J: Rats were administered with STZ $45 \mathrm{mg} / \mathrm{kg}$ b.w. + NA $110 \mathrm{mg} / \mathrm{kg}$ b.w. + HFD + ethyl acetate fraction of chayote extract $150 \mathrm{mg} / \mathrm{kg}$ b.w., and Group K: Rats were administered with STZ $45 \mathrm{mg} / \mathrm{kg}$ b.w. + NA $110 \mathrm{mg} / \mathrm{kg}$ b.w. + HFD + metformin $40.5 \mathrm{mg} / \mathrm{kg}$ b.w.

\section{Preparation of chayote ethanolic extracts}

The chayote ethanolic extract was obtained through the maceration process using ethanol $80 \%$. About 10 simplicia and 75 parts of the solvent were kept in a stoppered container for 5 days with frequent agitation until the soluble matter is dissolved. The liquid phase was separated from the solid material with frequent filtration. A sufficient amount of solvent was added to solid residue until the liquid collected is 100 parts. The liquid phase was then moved to another tightly stoppered container, was protected from sunlight, and placed in cool space for 2 days. The layer of liquid 
closer to the top of the container was separated from the other material with decantation. The concentrated ethanolic extract was then resulted using a rotary evaporator at $40^{\circ} \mathrm{C}$ set of temperature.

\section{Preparation of ethyl acetate fraction}

About $20 \mathrm{~g}$ of concentrated chayote ethanolic extract was mixed with $50 \mathrm{ml}$ of ethanol $96 \%$ and $100 \mathrm{ml}$ aquadest until homogenous. The mixture was partitioned in the separator funnel using $100 \mathrm{ml}$ ethyl acetate until the liquid phase showed a negative response to $\mathrm{FeCl}_{3}$ and ethyl acetate fraction was formed. The concentrated ethyl acetate fraction was then resulted using a rotary evaporator at $40^{\circ} \mathrm{C}$ set of temperature.

\section{Hyperglycemia induction}

Rats were treated with NA (110 mg/kg b.w.) with a $15 \mathrm{~min}$ interval to the following intraperitoneal injection of $45 \mathrm{mg} / \mathrm{kg}$ b.w. cold STZ in $\mathrm{NaCl} 0.9 \%$. Wistar rat is categorically suffered from diabetes mellitus (DM) if the level of blood sugar is $>250 \mathrm{mg} / \mathrm{dl}$ after $72 \mathrm{~h}$ of induction [13], [14].

\section{Insulin resistance induction with HFD}

The formula used is a modification of Listianasari et al. [15] formula. The rat was fed with HFD from the mixture of egg yolk, coconut oil, and butter. This diet was given using a gastric/feeding tube in the amount of $4 \mathrm{ml} /$ day/rat.

\section{Glucose loading}

The rats were fasted and fed with chayote extract. The rats were 30 min later loaded with glucose $75 \mathrm{~g}$ (dosage for rats converted to $1.35 / 200 \mathrm{~g} \mathrm{b.w}$ ). The BSL after $1 / 2 h, 1 \mathrm{~h}, 1 \frac{1}{2} \mathrm{~h}$, and $2 \mathrm{~h}$ was then measured. The rat body weight was measured using a balance and BSL was measured with a spectrophotometer. The activities of malondialdehyde (MDA), superoxide dismutase (SOD), insulin level, and HOMA-IR were measured using ELISA.

\section{Statistical analysis}

One-way analysis of variance and KruskalWallis tests are used to determine if there are statistically significant differences between two or more groups of treatment in this research. Wilcoxon signed-rank test and dependent T-test are used as needed. The level of significance was set at $p<0.05$. Statistical analyses were performed with SPSS, version 18 (SPSS Inc., Chicago, IL, USA).

\section{Results}

\section{Body weight of rats}

The result showed that the rats model has had the proper body weight relevant to the inclusion criteria. Body weight of the rats after the diabetic induction and body weight after extract treatment in the $2^{\text {nd }}-3^{\text {rd }}$ weeks are shown in Table 1.

Table 1: Body weight of rats before and after induction and extract treatment

\begin{tabular}{lllll}
\hline Groups & Groups & & \\
\cline { 2 - 5 } & Week 0 & Week 1 & Week 2 & Week 3 \\
\hline A & $159.33 \pm 12.10$ & $159.67 \pm 12.42$ & $162.00 \pm 12.77$ & $163.33 \pm 12.34$ \\
B & $178.33 \pm 21.36$ & $245.00 \pm 77.97$ & $222.67 \pm 61.72$ & $203.67 \pm 22.50$ \\
C & $157.67 \pm 4.51$ & $222.67 \pm 10.02$ & $215.67 \pm 5.03$ & $145.33 \pm 28.02$ \\
D & $195.00 \pm 33.78$ & $222.67 \pm 5.86$ & $201.33 \pm 12.06$ & $226.83 \pm 66.23$ \\
E & $164.75 \pm 32.35$ & $179.25 \pm 27.54$ & $178.50 \pm 35.26$ & $176.63 \pm 37.24$ \\
F & $178.25 \pm 9.39$ & $199.25 \pm 13.55$ & $178.50 \pm 11.03$ & $149.50 \pm 47.26$ \\
G & $184.50 \pm 14.62$ & $208.75 \pm 24.30$ & $207.25 \pm 20.45$ & $207.88 \pm 22.23$ \\
H & $145.00 \pm 25.31$ & $171.75 \pm 34.36$ & $168.00 \pm 20.20$ & $153.88 \pm 8.76$ \\
I & $146.25 \pm 38.86$ & $141.25 \pm 34.48$ & $144.00 \pm 39.56$ & $121.25 \pm 26.39$ \\
J & $170.25 \pm 41.96$ & $187.00 \pm 49.09$ & $186.50 \pm 56.25$ & $178.13 \pm 57.50$ \\
K & $170.75 \pm 26.91$ & $182.00 \pm 23.57$ & $177.50 \pm 31.03$ & $182.88 \pm 26.05$ \\
p-value & $0.361^{* *}$ & $0.038^{* *}$ & $0.105^{*}$ & $0.023^{*}$ \\
\hline${ }^{*}$ Analysis of variance test, ${ }^{* *}$ Kruskal-Wallis test & & \\
\multicolumn{2}{l}{} & & &
\end{tabular}

Based on the measurement of body weight (Table 1), the lowest body weight at the beginning of the experiment is found in Group $\mathrm{H}$ with average weight of $145 \pm 25.31 \mathrm{~g}$, at which rats were treated with STZ 45 mg/kg b.w., NA 110 mg/kg b.w., HFD, and ethyl acetate fraction of chayote extract $45 \mathrm{mg} / \mathrm{kg}$ b.w. Meanwhile, the highest weight is $195 \pm 33.78 \mathrm{~g}$ in a group of positive control, at which rats were treated with NA 110 $\mathrm{mg} / \mathrm{kg}$ b.w. and HFD (Group D). There is no significant difference between the groups assessed.

In the following week after glucose induction, the lowest body weight $(141.25 \pm 34.48 \mathrm{~g})$ in the $1^{\text {st }}$ week is found in group of rats that were treated with STZ 45 mg/kg b.w., NA 110 mg/kg b.w., HFD, and ethyl acetate fraction of chayote extract $100 \mathrm{mg} / \mathrm{kg}$ b.w. (Group I) while the highest $(245 \pm 77.97 \mathrm{~g})$ is the positive control treated with STZ $45 \mathrm{mg} / \mathrm{kg}$ b.w., NA $110 \mathrm{mg} / \mathrm{kg}$ b.w., and HFD (Group B). No significant difference is found among the group in week 1 . In week 2 , the lowest weight is in the group treated with STZ $45 \mathrm{mg} / \mathrm{kg}$ b.w., NA $110 \mathrm{mg} / \mathrm{kg}$ b.w., HFD, and ethyl acetate fraction of chayote extract $100 \mathrm{mg} / \mathrm{kg}$ b.w. with Group B stays in the highest weight among the group. However, there is no significant difference among the groups. In week 3, a Group I also has the lowest weight among all, while Group D that shows the highest weight in week 0 stays in the highest position in week 3. $p<0.05$ shows that there is a difference among groups in this week.

\section{Glucose loading}

The result of the glucose load for the rats is shown in Table 2 . In the $1^{\text {st }}$ week of treatment, the highest fasting BSL is found in Group F with an average value of $337.50 \pm 140.22$. The lowest is found in Group 


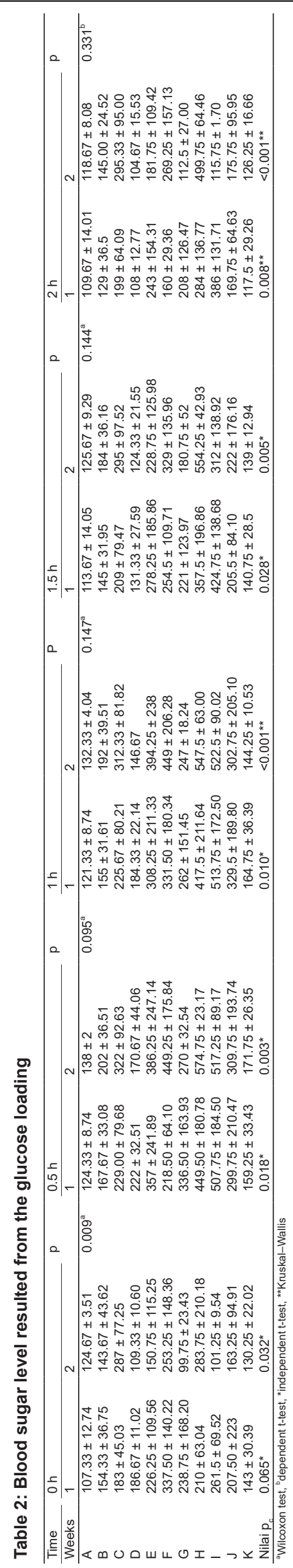

A with an average value of $107.33 \pm 12.74$. There is no significant difference between each group.

The highest BSL of the rats loaded with glucose, $30 \mathrm{~min}$ after the treatment, is around $507.75 \mathrm{mg} / \mathrm{dl}$ founded in Group I while the lowest average value is $124.33 \pm 8.74 \mathrm{mg} / \mathrm{dl}$ in Group A. $p<0.05$ shows that there is the difference in the results of the groups. From the measurement $1 \mathrm{~h}$ after glucose load, the highest BSL is found in Group I ( $513.75 \pm 172.50 \mathrm{mg} / \mathrm{dl})$ while the lowest in Group A (121.33 $\pm 8.74 \mathrm{mg} / \mathrm{dl})$. $\mathrm{p}<$ 0.05 means that it is significantly different in groups. From the measurement $2 \mathrm{~h}$ after glucose load, the highest is in Group I with the average value of BSL 386 $\pm 131.71 \mathrm{mg} / \mathrm{dl}$ while the lowest group founded in Group D with average $104.67 \pm 15.53 \mathrm{mg} / \mathrm{dl}$. From the treated group, the average of the lowest BSL is in Group K $117.5 \pm 29.26$. $p<0.01$ shows that there is a difference in groups. In the $2^{\text {nd }}$ week, the fasting BSL of the rats was measured. The highest is in Group $C$ $(287 \mathrm{mg} / \mathrm{dl})$ while the lowest is Group $\mathrm{G}(99.75 \mathrm{mg} / \mathrm{dl})$. $p<0.05$ shows that there is a difference in groups. From the measurement 30 min after glucose load, the group with the highest BSL is Group H $(574.75 \mathrm{mg} / \mathrm{dl})$ while the lowest level is in Group A (138 mg/dl). $p<0.01$ means that there is a difference among the groups.

The highest average of BSL in the measurement of $1 \mathrm{~h}$ afterload is in Group $\mathrm{H}$ with the level of $547.5 \pm$ $63.00 \mathrm{mg} / \mathrm{dl}$, while the lowest average is in Group A with BSL $132.33 \pm 4.04$. $p<0.001$ means that there is a difference in groups. The highest average BSL in 1.5 $\mathrm{h}$ is in Group H with $554.25 \pm 42.93 \mathrm{mg} / \mathrm{dl}$, while the lowest BSL average is in Group A $125.67 \pm 9.29 \mathrm{mg} / \mathrm{dl}$. $p<0.01$ means that there is a difference in groups. From the measurement $2 \mathrm{~h}$ after glucose load, the checking glucose load in $2 \mathrm{~h}$, the highest average value in Group $\mathrm{H}$ is $499.75 \pm 64.46 \mathrm{mg} / \mathrm{dl}$, meanwhile, the lowest average is in Group A $118.67 \pm 8.08$. For the therapy group, the lowest BSL average value is in Group G $112.5 \pm 27.00 \mathrm{mg} / \mathrm{dl} . \mathrm{p}<0.001$ means that there is a difference in groups.

If we compare the average of fasting BSL between the $1^{\text {st }}$ and $2^{\text {nd }}$ weeks, the highest average value is found in week 1 Group $F$ with average value $337.50 \pm 140.22 \mathrm{mg} / \mathrm{dl}$. Meanwhile, the lowest average found in week 2 Group I with average value BSL 101.25 $\pm 9.54 \mathrm{mg} / \mathrm{dl} . \mathrm{p}<0.01$ means that there is a difference between each group.

From the average glucose loaded in $30 \mathrm{~min}$ after oral glucose load, the lowest BSL is found in the treated Group K in week 1 with an average value of $159.25 \pm 33.43 \mathrm{mg} / \mathrm{dl}$. Meanwhile, the highest BSL is found in week 2 Group H with average BSL $574.75 \pm$ $23.17 \mathrm{mg} / \mathrm{dl}$. The $\mathrm{p}$-value shows no difference among the groups. However, Group K shows the ability of metformin in decreasing the BSL in 30 min after giving the glucose, followed by Group F treated with extract ethanol $100 \mathrm{mg} / \mathrm{kg}$ b.w. with BSL average $218.50 \pm$ $64.10 \mathrm{mg} / \mathrm{dl}$. 
From the average glucose loaded in $1 \mathrm{~h}$ after oral glucose load, the group that has the lowest average of BSL is also Group $\mathrm{K}$ in the $2^{\text {nd }}$ week with an average value of $144.25 \pm 10.53 \mathrm{mg} / \mathrm{dl}$. The highest average value is also in Group $F$ the $2^{\text {nd }}$ week with average BSL $449 \pm 206.28 \mathrm{mg} / \mathrm{dl}$. There is no significant difference showed among the groups. However, Group $\mathrm{K}$ also shows the metformin ability in decreasing BSL in $1 \mathrm{~h}$ after giving the glucose. It is also followed by Group $\mathrm{F}$ that was treated with ethanol extract $150 \mathrm{mg} / \mathrm{kg}$ b.w. with the average BSL $247 \pm 18.24 \mathrm{mg} / \mathrm{dl}$.

From the measurement of glucose loaded in $1.5 \mathrm{~h}$ after glucose was given, the highest BSL is in the $2^{\text {nd }}$ week in Group E with the average value of 554.25 $\pm 42.93 \mathrm{mg} / \mathrm{dl}$. Meanwhile, the lowest BSL is in the $2^{\text {nd }}$ week in Group K $139 \pm 12.94$, followed by Group G for the $2^{\text {nd }}$ week with BSL average $180.75 \pm 52 \mathrm{mg} / \mathrm{dl}$. $p=0.144$ shows the difference among the groups even though Groups K and $\mathrm{G}$ show the decreasing of clinical BSL.

From the measurement of glucose loaded in $2 \mathrm{~h}$ after glucose was given, the highest BSL is in week 2 in Group $\mathrm{H}$ with an average value of 499.75 $\pm 64.46 \mathrm{mg} / \mathrm{dl}$. Meanwhile, the lowest BSL is found in week 2 Group $G$ with an average value of $112.5 \pm$ 27.00. There is no significant difference showed in the $2 \mathrm{~h}$ glucose load. The average BSL in Group $\mathrm{G}$ is, however, clinically lower compared with Group K which was treated with metformin. It is even lower than the healthy or untreated group.

\section{Measurement of SOD, MDA, BSL, and HOMA-AIR}

Data of the measurement of SOD, MDA, BSL, insulin, and HOMA-IR on the $3^{\text {rd }}$ week are shown in Table 3.

Table 3: Data from the analysis of SOD, MDA, BSL, insulin, and HOMA-IR

\begin{tabular}{llllll}
\hline Kelompok & SOD & MDA & BSL & Insulin & HOMA-IR \\
\hline $\mathrm{A}$ & $1.09 \pm 0.26$ & $0.689 \pm 0.03$ & $186.38 \pm 9.70$ & $4.60 \pm 1.15$ & $2.12 \pm 0.59$ \\
$\mathrm{~B}$ & $0.26 \pm 0.40$ & $0.79 \pm 0.10$ & $215.57 \pm 93.18$ & $2.53 \pm 2.30$ & $1.69 \pm 1.73$ \\
$\mathrm{C}$ & $0.88 \pm 0.77$ & $0.89 \pm 0.08$ & $413.09 \pm 200.63$ & $4.64 \pm 3.80$ & $5.87 \pm 4.97$ \\
$\mathrm{D}$ & $1.74 \pm 0.29$ & $1.11 \pm 0.14$ & $276.69 \pm 62.34$ & $5.02 \pm 4.15$ & $3.79 \pm 3.24$ \\
$\mathrm{E}$ & $1.10 \pm 0.75$ & $1.59 \pm 0.69$ & $155.16 \pm 31.92$ & $0.44 \pm 0.24$ & $0.16 \pm 0.08$ \\
$\mathrm{~F}$ & $0.96 \pm 0.83$ & $1.40 \pm 0.23$ & $167.06 \pm 24.34$ & $6.88 \pm 1.00$ & $2.83 \pm 0.59$ \\
$\mathrm{G}$ & $1.00 \pm 0.82$ & $1.19 \pm 0.27$ & $187.18 \pm 54.57$ & $3.88 \pm 2.42$ & $1.68 \pm 1.09$ \\
$\mathrm{H}$ & $1.27 \pm 0.20$ & $0.86 \pm 0.07$ & $229.58 \pm 29.93$ & $6.14 \pm 0.71$ & $3.44 \pm 0.26$ \\
$\mathrm{I}$ & $1.10 \pm 0.74$ & $1.00 \pm 0.28$ & $163.12 \pm 14.62$ & $3.78 \pm 2.41$ & $1.46 \pm 0.89$ \\
$\mathrm{~J}$ & $1.05 \pm 1.26$ & $1.50 \pm 0.18$ & $278.08 \pm 56.74$ & $4.71 \pm 3.39$ & $3.32 \pm 2.83$ \\
K & $0.47 \pm 0.85$ & $1.24 \pm 0.10$ & $150.54 \pm 17.24$ & $4.58 \pm 3.70$ & $1.75 \pm 1.51$ \\
P-value & $0.525^{* *}$ & $0.001^{*}$ & $0.001^{*}$ & $0.188^{* *}$ & $0.071^{*}$ \\
\hline${ }^{*}$ Analysis of variance, ${ }^{* *}$ Kruskal-Wallis & & &
\end{tabular}

The highest SOD level in the extract treated group is found in Group $\mathrm{H}$ with ethyl acetate $45 \mathrm{mg} / \mathrm{kg} \mathrm{b.w}$. treatment. The average level is 1.27 \pm 0.20 . Meanwhile, the group with the lowest level of SOD is Group F which was treated with $100 \mathrm{mg}$ ethanol extract $/ \mathrm{kg}$ b.w. resulted SOD $0.96 \pm 0.83$. There were no significant differences between groups, however, the treatment of extracts in Group $\mathrm{H}$ was able to increase SOD antioxidants higher than other groups.
The highest MDA level is in Group $E$ with $45 \mathrm{mg} / \mathrm{kg}$ b.w. ethanol extract treatment, which is $1.59 \pm$ 0.69 . The lowest is $0.86 \pm 0.07$ founded in Group $\mathrm{H}$ with $45 \mathrm{mg} / \mathrm{kg}$ b.w. ethyl acetate treatment. $p=0.001$ means that there are significant differences between groups. Group $\mathrm{H}$ extract can reduce oxidative stress better than other groups.

The lowest spectrophotometer of fasting BSL is in $\mathrm{K}$ group treated with metformin with the level of $150.54 \pm 17.24 \mathrm{mg} / \mathrm{dl}$, followed by Group $\mathrm{E}$ treated with $45 \mathrm{mg} / \mathrm{kg}$ b.w. ethanol, with the level of $155.16 \pm$ $31.92 \mathrm{mg} / \mathrm{dl}$. $\mathrm{p}=0.001$ means that there are significant differences between groups although the group given the extract showed a decrease in BSL, the decrease in BSL was better in $\mathrm{K}$ group. Metformin has a strong ability of hypoglycemia compared to the other groups.

The highest level of insulin is in Group F which is $6.14 \pm 0.71$, the lowest level is in Group $E$ which is $0.44 \pm 0.24$ with $p=0.188$ it's mean that there is no significant difference between groups, but extract in Group $F$ could increase insulin secretion higher than with other groups. The highest HOMA-IR in Group $\mathrm{H}$ is $3.44 \pm 0.26$, while the lowest is in Group E $0.16 \pm$ 0.08 with no significant difference between groups. Nonetheless, Group E resistance insulin was decreased compared to other groups who received extracts or oral hypoglycemia.

\section{Discussion}

The group treated with extract and fractionation has better weight loss in Group I both at days 1, 2, and 3, compared with metformin. Fractionation of ethyl acetate chayote $100 \mathrm{mg} / \mathrm{kg}$ b.w. reduced the mass of adipose tissue in the body due to fractionation that inhibits mobilization of fat from peripheral adipose tissue to plasma [16]. It proves that ethyl acetate fraction can inhibit the performance of the pancreatic lipase enzyme as an enzyme that plays an important role in fat metabolism and fat absorption. Moreover, ethyl acetate fraction also plays a role in inhibiting $\alpha$-glucosidase, thus reducing the absorption of carbohydrate [17], [18], [19].

Nevertheless, research conducted by Olaokun et al. [19] shows the different results with this study. The ethyl acetate fraction used did not reduce weight and the mechanism of the failure of ethyl acetate fraction in losing weight could not be fully explained. They assumed that the fraction ethyl acetate failed to inhibit the lipase enzyme while the ethyl acetate fraction was able to inhibit $\alpha$-glucosidase in vitro [19].

Group $G$ had a higher average body weight than the other groups in every week. However, the increase in body weight did not indicate clinical deterioration from the glucose loading. This group 
had the lowest reduction in a mean of BSL $(112.5 \pm$ $27.00 \mathrm{mg} / \mathrm{dl})$. Meanwhile, Group $\mathrm{G}$ which was treated with ethanol extract $150 \mathrm{mg} / \mathrm{kg}$ b.w. was able to withstand weight loss. This condition happened due to the presence of saponins which acted like insulin that stimulating glucose absorption with Glut4 expression raise, contributing in the store of glucose in adipocyte cells in the form of glycogen through stimulation of glycogenesis in glycogen synthetase, and inhibiting the enzyme gluconeogenesis of glycogen phosphorylase [20], [21], [22], [23].

Weight loss can also be an indicator of improved insulin sensitivity and well-controlled glycemic. However, while there was weight loss in Group $C$ at week 3, weight gain occurs in the control Groups A, B, $C$, and D induced by STZ-NA-HFD which could also be caused by the impaired insulin performance [22]. In DM, glycogen synthesis in rat liver and skeletal muscle is disrupted. The regulation of glycogen metabolism occurs by the enzymes glycogen synthase and glycogen phosphorylase that play a major role in glycogen metabolism. The decreasing of experimental muscle glycogen storage of diabetic rats has been associated with reduced glycogen synthase activity and increased glycogen phosphorylase activity [21]. Weight loss in Group $\mathrm{C}$ was caused by the poor insulin performance in which Group $\mathrm{C}$ had the highest average insulin resistance level of $5.87 \pm 4.97$. Therefore, there are indications of beta-cell damage resulting from hypoinsulinemia, hyperglycemia, and followed by excessive breakdown of muscle protein and fat to meet the energy requirements that are lacking due to the inadequacy of carbohydrates as an energy supplier. There was also a decrease in the rest of the extract treated groups with a value below the range of Group I [15], [24], [25], [26].

A glucose load test was performed to determine the body's ability to use glucose as the main source [26]. In all groups in this study, the mean of BSL 30 min after loading was increased, reaching a peak at $1 \mathrm{~h}$ after loading and going back down at $1.5 \mathrm{~h}$ and $2 \mathrm{~h}$ after glucose loading. Groups that have a good ability to use glucose from 30 min to $2 \mathrm{~h}$ after loading were the group with metformin treatment, Group K while the group with the lowest mean of BSL was in Group I with a value of $115.75 \pm 1.70 \mathrm{mg} / \mathrm{dl}$. Even though metformin rapidly reduced the mean of $\mathrm{BSL}$ starting from $30 \mathrm{~min}$, the effectiveness of hypoglycemia in $2 \mathrm{~h}$ after loading was not better when compared with Group I who received $100 \mathrm{mg} / \mathrm{kg}$ b.w. ethyl acetate fractionation. The effects of hypoglycemia fractionation are caused by flavonoids, alkaloids, triterpene, glycosides, and saponins which result in the accumulation of glycogen through glycogen synthetase which is stimulated by insulin secretion [26].

Phytochemical in fruits and vegetables has an important role in reducing oxidative stress. The content of non-enzymatic antioxidants such as $A$, C, E, and enzymatic antioxidants such as SOD and CAT in fruits and vegetables is active compounds for reducing oxidative stress [27]. In this study, the highest enzymatic antioxidant SOD was in Group $\mathrm{H}$ treated with ethyl acetate $45 \mathrm{mg} / \mathrm{kg}$ b.w. Ethyl acetate fraction can increase SOD which acts as a first-line antioxidant that is able to withstand ROS. The SOD protects cells from ROS by reducing oxygen radicals, which damages membranes and biological structures. SOD can catalyze disposal oxygen radicals to $\mathrm{H}_{2} \mathrm{O}_{2}$ which then deactivated to $\mathrm{H}_{2} \mathrm{O}$ by CAT. The SOD can act as a major defense against ROS and prevent further production of free radicals. The SOD activity was found to be lower in diabetic subjects due to inactivation by $\mathrm{H}_{2} \mathrm{O}_{2}$ or by enzyme glycation, which occurs in diabetes. CAT is a protein heme, which is present in almost all mammalian cells and is responsible for reducing $\mathrm{H}_{2} \mathrm{O}_{2}$ to protect cells from highly reactive $\mathrm{OH}$ radicals. The reduced CAT activity can also be caused by inactivation by the glycation enzyme. Any combination with antioxidant properties can contribute to the reduction of partial or total oxidative damage. As a result, eliminating oxygen radicals and hydroxyl radicals are perhaps one of the most effective defenses against disease. This research shows that treatment with ethyl fraction $45 \mathrm{mg} / \mathrm{kg}$ b.w. can increase SOD activity as a compensatory mechanism against high oxidative stress precursors such as superoxide, hydroxyl radicals, and hydrogen peroxide, which are free radicals that are most often found in hyperglycemia conditions [27], [28].

Flavonoids have been proven to be good antioxidants in the treatment of oxidative stress induced by STZ [21]. Oxidative stress levels assessed by MDA markers were lower in the $\mathrm{H}$ group given ethyl acetate $45 \mathrm{mg} / \mathrm{kg}$ b.w. This was due to the high antioxidant SOD that could reduce free radicals so that oxidative stress decreased in this group [27], [28].

Liver plays a role in regulating glucose homeostasis through insulin that regulates glucose homeostasis between incoming glucose (glucose uptake and glycogen synthesis) and glucose out (glycogenolysis and gluconeogenesis). Insulin mediates physiological processes through different mechanisms involving increasing levels of plasma membrane glucose transporter 4 (GLUT4); hexokinase stimulation and glycogen synthase kinase 3 (GSK3); inhibition of glycogen phosphorylase; phosphoenolpyruvate carboxykinase (PEPCK); and glucose-6-phosphatase (G6Pase). The decrease in liver glycogen may be caused by the decrement of GLUT4 regulation, hexokinase, and GSK3 due to the absence of insulin [29]. In this research, the lowest insulin levels were in Group E which received ethanol extract $45 \mathrm{mg} / \mathrm{kg}$ b.w. with insulin levels $0.44 \pm 0.24$. Although insulin levels were low in Group E, insulin resistance was also low in $0.16 \pm 0.08$. The level of fasting BSL in the spectrophotometry showed mean levels of $155.16 \pm 31.92$. This situation shows that ethanol extract $45 \mathrm{mg} / \mathrm{kg}$ b.w. did not stimulate insulin but increases insulin sensitivity. 


\section{Conclusion}

Ethyl acetate fraction, even the lowest dose, was better in reducing the body weight of rat compared to ethyl fraction $100 \mathrm{mg} / \mathrm{kg}$ b.w. and $150 \mathrm{mg} / \mathrm{kg} \mathrm{b.w.;}$ and even better than other treated and control groups. Ethanol extract $150 \mathrm{mg} / \mathrm{kg}$ b.w. was able to increase body weight better than ethanol $45 \mathrm{mg} / \mathrm{kg} \mathrm{b.w.} \mathrm{nor} 150 \mathrm{mg} / \mathrm{kg}$ b.w. nor with ethyl acetate fraction. Ethyl acetate fraction $100 \mathrm{mg} / \mathrm{kg}$ b.w. was able to reduce BSL in $2 \mathrm{~h}$ loading better than other treatment groups. Ethyl acetate fraction $45 \mathrm{mg} / \mathrm{kg}$ b.w. could increase the endogenous antioxidant activity of SOD while reducing oxidative stress. Ethanol extract $45 \mathrm{mg} / \mathrm{kg} \mathrm{b.w}$. was unable to stimulate insulin secretion while having hypoglycemia capacity through the raise of insulin sensitivity. Ethanol extract $45 \mathrm{mg} / \mathrm{kg}$ b.w. could decrease insulin sensitivity.

\section{References}

1. Sheikhpour R. Diabetes and oxidative stress: The mechanism and action. Iran J Diabetes Obes. 2013;5(1):40-5.

2. Ganjifrockwala FA, Joseph JT, George G. Decreased total antioxidant levels and increased oxidative stress in South African Type 2 diabetes mellitus patients. J Endocrinol Metab Diabetes South Afr. 2017;22(2):21-5. https://doi.org/10.1080/16 089677.2017.1324590

3. Tangvarasittichai S. Oxidative stress, insulin resistance, dyslipidemia and Type 2 diabetes mellitus. World J Diabetes. 2015;6(3):456-80. https://doi.org/10.4239/wjd.v6.i3.456 PMid:25897356

4. Holt RI. Diagnosis, epidemiology and pathogenesis of diabetes mellitus: An update for psychiatrists. Br J Psychiatry. 2004;47:S55-63. https://doi.org/10.1192/bjp.184.47.s55 PMid:15056594

5. Wallace TM, Levy JC, Matthews DR. Use and abuse of HOMA modeling. Diabetes Care. 2004;27(6):1487-95. https://doi org/10.2337/diacare.27.6.1487

PMid:15161807

6. Popa S, Mota M. Beta-cell Function and Failure in Type 2 Diabetes. London, United Kingdom: IntechOpen; 2013.

7. Kaku K. Pathophysiology of Type $2 \mathrm{DM}$ and its treatment policy. JMAJ. 2010;53(1):41-6.

8. Ozougwu JC, Obimba KC, Belonwu CD, Unakalamba CB. The pathogenesis and pathophysiology of Type 1 and Type 2 diabetes mellitus. Acad J. 2013;4(4):46-57.

9. Stauffacher W, Burr I, Gutzeit A, Beaven D, Veleminsky J, Renold AE. Streptozotocin diabetes: Time course of irreversible B-cell damage; further observations on prevention by nicotinamide. Exp Biol Med. 1970;133(1):194-200. https://doi. org/10.3181/00379727-133-34439

10. Szkudelski T. Streptozotocin-nicotinamide-induced diabetes in the rat. Characteristics of the experimental model. Exp Biol Med. 2012;237(5):481-90. https://doi.org/10.1258/ebm.2012.011372 PMid:22619373

11. Siahaan JM, Harahap U, Loesnihari R. Effect of ethanol extract of chayote (Sechium edule Jacq. Swartz) on the activity of glutathione peroxide (GPx) in house mice (Mus musculus L) strain DD webster hyperglycemia induced by streptozotocin (STZ). Indones J Med. 2016;1(1):44-9. https://doi.org/10.26911/ theijmed.2016.01.01.06

12. Siahaan, JM. Effect of antihipoglycemic Sechium edule Jacq. Swartz. Etanol extract on histopathologic changes in hyperglycemic Mus musculus L. Indones J Med. 2017;2(2):8693. https://doi.org/10.26911/theijmed.2017.02.02.02

13. Pari L, Karthikesan K, Menon VP. Comparative and combined effect of chlorogenic acid and tetrahydrocurcumin on antioxidant disparities in chemical induced experimental diabetes. Mol Cell Biochem. 2010;341(1-2):109-17. https://doi.org/10.1007/ s11010-010-0442-5

PMid:20339905

14. Firdous SM, Singh A. Effect of Ipomoea staphylina leaves on streptozotocin-nicotinamide induced Type-II diabetes in Wistar. Asian Pac J Health Sci. 2016;3(3):30-44. https://doi. org/10.21276/apjhs.2016.3.3.6

15. Listianasari $Y$, Dirgahayu $P$, Wasita $B$, Nuhriawangsa $A$, Magna P. Efektivitas pemberian jus labu siam (Sechium edule) terhadap profil lipid tikus (Rattus novergicus) model hiperlipidemia. Penelitian Gizi Makanan. 2017;40(1):35-43. https://doi.org/10.22435/pgm.v40i1.6046.35-43

16. Leite AC, Araujo TG, Carvalho BM, Maia MB, Lima VL. Characterization of the antidiabetic role of Parkinsonia aculeata (Caesalpineaceae). Evid Based Complement Alternat Med. 2011;9:692378. https://doi.org/10.1155/2011/692378

17. Sornalakshmi V, Tresina SP, Paulpriya K, Packia LM, Mohan VR. Oral glucose tolerance test (OGTT) in normal control and glucose induced hyperglycemic rats with Hedyotis leschenaultiana DC. Int J Toxicol Pharmacol Res. 2016;8(1):5962. https://doi.org/10.1201/9780429487767-22

18. Sulaiman CT, Shahida V, Balachandran I. Effect of extraction solvent on the phytoconstituents of Aegle marmelos (L.) correa. J Natl Remedies. 2015;15(1):58-64. https://doi.org/10.18311/ jnr/2015/498

19. Olaokun OO, McGaw LJ, Rensburg IJ, Jacobus N, Eloff JN, Naidoo V. Antidiabetic activity of the ethyl acetate fraction of Ficus lutea (Moraceae) leaf extract: Comparison of an in vitro assay with an in vivo obese mouse model. BMC Complement Altern Med. 2016;16:110. https://doi.org/10.1186/s12906-016-1087-z PMid:27029351

20. Balasubramanian T, Chatterjee TK, Senthilkumar GP, Mani T. Effect of potent ethyl acetate fraction of Stereospermum suaveolens extract in streptozotocin-induced diabetic rats. ScientificWorldJournal. 2012;2012:413196. https://doi. org/10.1100/2012/413196 PMid:22593683

21. Kumarappan CT, Thilagam E, Vijayakumar M, Mandal SC. Modulatory effect of polyphenolic extracts of Ichnocarpus frutescens on oxidative stress in rats with experimentally induced diabetes. Indian J Med Res. 2012;136(5):815-21. https://doi.org/10.1016/j.sjbs.2012.04.004 PMid:23287129

22. Verma N, Amresh G, Sahu PK, Rao CV, Singh AP. Antihyperglycemic and antihyperlipidemic activity of ethyl acetate fraction of Rhododendron arboreum smith flowers in streptozotocin induced diabetic rats and its role in regulating carbohydrate metabolism. Asian Pac J Trop Biomed. 2012;2(9):696-701. https://doi.org/10.1016/ s2221-1691(12)60212-3

PMid:23569997

23. Okoduwa SI, Umar IA, James DB, Inuwa HM. Anti-diabetic potential of Ocimum gratissimum Leaf fractions in fortified diet-fed streptozotocin treated rat model of Type-2 diabetes. Medicines (Basel). 2017;4(4):73. https://doi.org/10.3390/ medicines4040073 
PMid:29019956

24. Mousavi L, Mohd SR, Murugaiyah V, Asmawi MZ. Hypoglycemic and anti-hyperglycemic study of Ocimum tenuiflorum L. Leaves extract in normal and streptozotocin-induced diabetic rats. Asian Pac J Trop Biomed. 2016;6(12):1029-36. https://doi. org/10.1016/j.apjtb.2016.10.002

25. Mhya DH, Anigo KM, Umar IA, Alegbejo JO. Evaluation of anti-hyperglycemic effect of sub-fractions derived from ethanol-aqueous fraction of Balanites aegyptiaca leaves in streptozotocin-induced diabetic rats. Asian J Biol Sci. 2019;12(2):164-72. https://doi.org/10.3923/ajbs.2019.164.172

26. Hossain MS, Khan MR, Anisuzzaman AS, Ahmed M, Amran MS, Islam A. Antidiabetic and glycogenesis effects of different fractions of ethanolic extract of leaves of Mangifera indica (Linn.) in normal and alloxan induced diabetic rats. J Med Sci. 2010;10:80-6. https://doi.org/10.3923/jms.2010.80.86

27. Aboonabi A, Rahmat A, Othman F. Antioxidant effect of pomegranate against streptozotocin-nicotinamide generated oxidative stress induced diabetic rats. Toxicol Rep. 2014;1:91522. https://doi.org/10.1016/j.toxrep.2014.10.022

PMid:28962304

28. Ononamadu CJ, Alhassan AJ, Ibrahim A, Imam AA, Ihegboro GO, Owolarafe TA, et al. Methanol-extract/fractions of Dacryodes edulis Leaves ameliorate hyperglycemia and associated oxidative stress in streptozotocin-induced diabetic Winstar rats. J Evid Based Integr Med. 2019;24:1-12. https:// doi.org/10.1177/2515690x19843832

PMid:31055945

29. Ubhenin B, Adamude FA, Dingwoke EJ, Nwobodo NN. Hypolipidamic study of ethyl acetate leaves extract of Momordica charantia on the biochemical parameters of streptozotocin-nicotinamide induced Type 2 diabetic rats. Biomed Res. 2019;30(4):201. https://doi.org/10.35841/ biomedicalresearch.30-19-201 